\title{
Desain Interior Perpustakaan Grhatama Pustaka yang Berkonsep Mandiri Rekreatif Sebagai Penunjang Aktivitas Pengguna
}

\author{
Puteri Nofa A., dan Anggra Ayu Rucitra \\ Departemen Desain Interior, Fakultas Arsitektur, Desain dan Perencanaan, Institut Teknologi Sepuluh \\ Nopember (ITS) \\ e-mail: anggraayurucita@gmail.com
}

\begin{abstract}
Abstrak-Budaya membaca adalah salah satu budaya di masyarakat yang harus dilestarikan. Dengan membaca semak in banyak ilmu yang dapat diserap. Namun seiring berjalannya waktu, minat masyarakat dalam membaca mulai menurun. BPAD DIY, sebagai lembaga arsip daerah, membangun sebuah perpustakaan umum namun juga memiliki fasilitas lain, s e pe rti bioskop, auditorium, dan sebagainya. Fasilitas tersebut nantinya dapat menjaga eksistensi dari perpustakaan ini. Namun beragamnya fasilitas yang ditawarkan, belum dioptimalkan pada setiap area, seperti pada area koleksi umum dimana banyaknya jumlah pengunjung yang masuk tidak sebanding dengan luasnya area, serta tidak terdapatnya area diskusi yang menyebabkan beberapa pengunjung kehilangan area privasi mereka. Dalam penyelesaian masalah, diterapkan beberapa metode seperti kuisioner, studi literasi dan observasi kepada pengunjung. Metode tersebut dilakukan dalam jangka waktu tertentu sepe rti pada kondisi ramai dan sepi, sehingga dapat diketahui permasalahan apa yang ada di perpustakaan. Berdasarkan analisa yang dilakukan, ditarik suatu konsep mandiri rekreatif yang dapat diterapkan pada perpustakaan. Penerapan konsepini bertujuan untuk lebih menarik minat pengunjung agar datang ke perpustakaan dan memberikan eksperimen baru tentang perpustakaan. Setelah desain diaplikasikan, akan dilakukan studi tingkat kepuasan pengunjung dan jumlah peningkatan pengunjung.
\end{abstract}

Kata Kunci-Desain Interior, Perpustakaan.

\section{PENDAHULUAN}

$\mathrm{M}$ EMBACA buku merupakan salah satu khasanah ilmu karena banyak ilmu yang dapat diserap, namun seiring berjalannya waktu, minat masyarakat dalam membaca mulai menurun terutama di Indonesia. Beberapa pihak seperti pemerintah sudah berusaha meningkatkan minat baca dengan cara meningkatkan jumlah perpustakaan yang ada baik perpustakaan bersifat umum maupun khusus.

Grhatama Pustaka BPAD DIY merupakan salah satu bentuk nyata dari upaya peningkatan membaca di Jogjakarta. Perpustakaan ini tidak hanya menyediakan buku tetapi juga fasilitas area braile, area khusus anak, bioskop 6D, serta ruang pertemuan, namun dengan beragamnya fasilitas yang ada kurang dibarengi dengan pemaksimalan fungsi ruangan.

Pada area koleksi umum, dimana area ini selalu ramai pengunjung sehingga menyebabkan ketidaknyamanan dan fasilitas yang disediakanpun tidak seimbang sehingga perlu perluasan area. Bentuk bangunan yang persegi dengan void ditengah tentu dengan mudah dapat membingungkan pengunjung karena hampir miripnya setiap sisi bangunan,

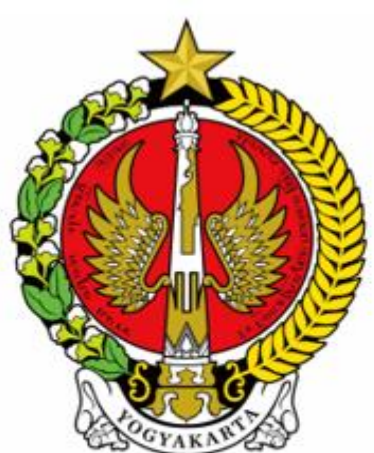

BADAN PERPUSTAKAAN DAN ARSIP DAERAH DAERAH ISTIMEWA YOGYAKARTA

Gambar 1. Logo BPAD DIY.

namun tingkat keterbacaan signage dan wayfinding yang masih kurang karena tidak dapat dipahami dengan mudah.

Perpustakaan ini juga memiliki area bagi anak, dimana pada area ini anak dibiarkan bermain dan belajar membaca dengan cara mereka sendiri. Namun, permainan yang ada kurang mendukung rasa motivasi bagi anak untuk belajar membaca buku.

Penerapan pembagian area serta adanya area khusus anak serta braile tentu memberikan nilai tambahan seperti dimana jenis perpustakaan ini masih sedikit di Indonesia oleh karena itu, untuk menunjang segala aspek kegiatan yang ada, pemilihan konsep mandiri rekreatif pada perpustakaan Grhatama Pustaka dapat membantu permasalahan yang ada baik dalam hal menarik minat pengujung dan juga kenyaman keamanan dari pengunjung

\section{II.TINJAUAN PUSTAKA}

\section{A. Perpustakaan Umum}

Perpustakaan Umum merupakan lembaga pendidikan bagi masyarakat umum dengan menyediakan berbagai informasi, ilmu pengetahuan, teknologi dan budaya sebagai sumber belajar untuk memperoleh dan meningkatkan ilmu pengetahuan bagi seluruh lapisan masyarakat [1]. Terdapat beberapa jenis perpustakaan umum [2] dari jenis-jenis tersebut perpustakaan Grhatama Pustaka BPAD DIY termasuk kedalam perpustakaan propinsi, dimana dalam penyelenggaraannya dikelola oleh propinsi dan mendukung pelestarian kebudayaan masing-masing. 


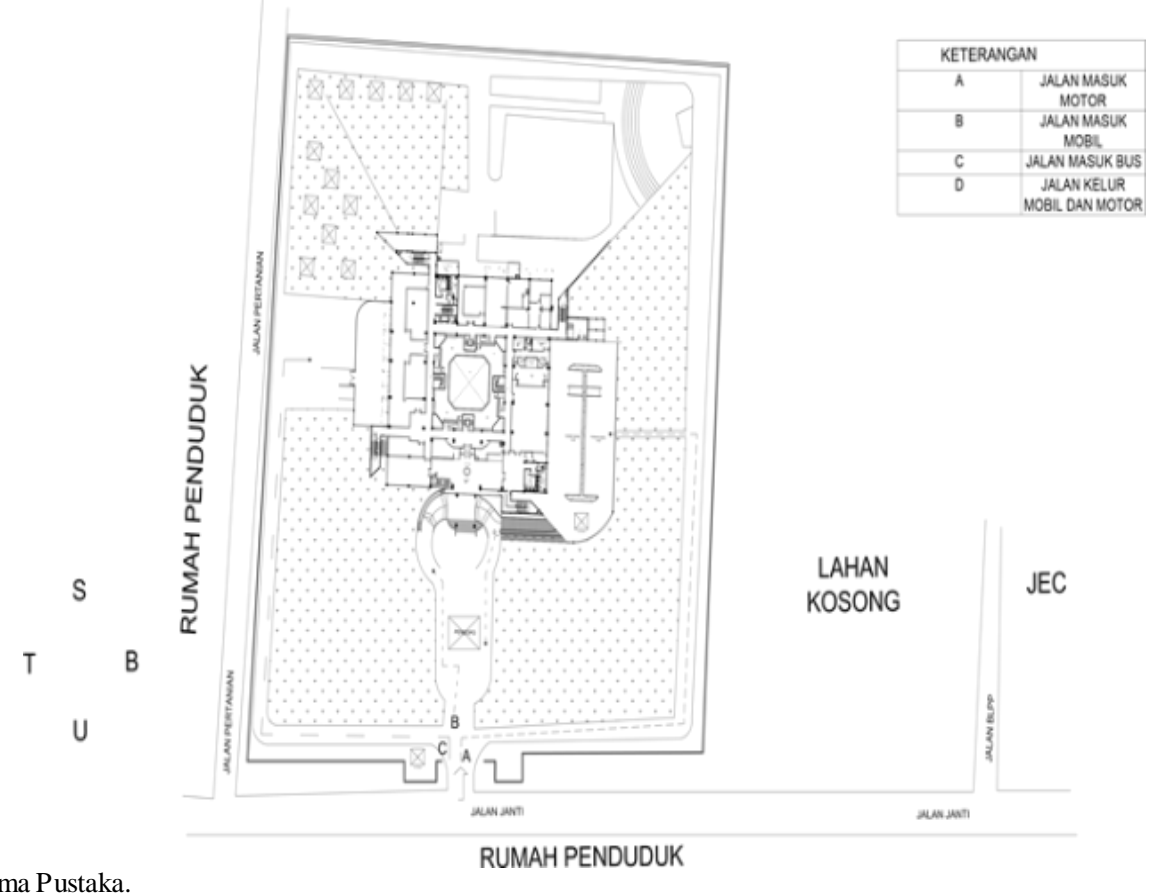

Gambar 2. Site plan Grhatama Pustaka.

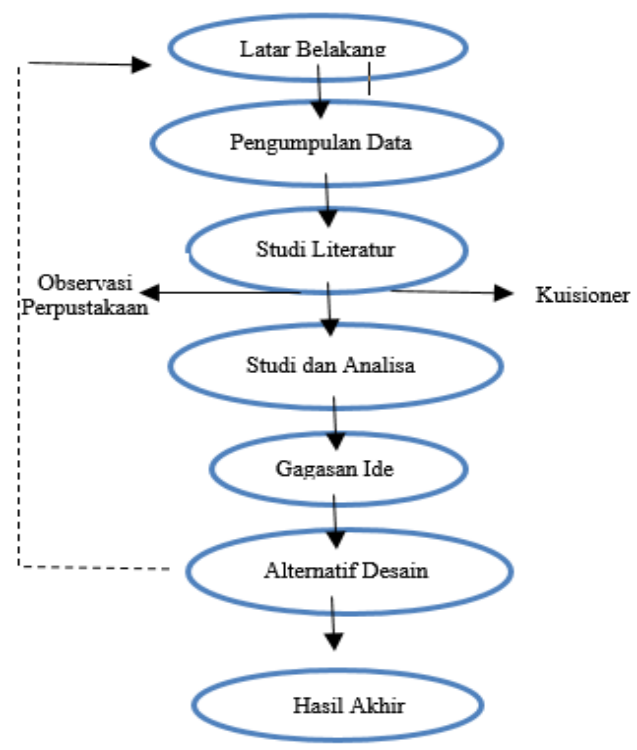

Gambar 3. Bagan Proses Desain.

Menurut Suwarno [3] terdapat 4 aspek yang perlu diperhatikan dalam penataan ruang perpustakaan, as pek-aspek, yaitu: aspek fungsional, aspek psikologis pengguna, aspek estetika, dan aspek keamanan bahan pustaka. Ketika aspekaspek penataan ruang perpustakaan tersebut mampu diterapkan mengikuti hakikatnya dengan baik, maka perpustakaan pastidapat menjadi tempat yang sangat kondusif sebagai penyimpan koleksi referensi dan informasi.

\section{B. BPAD DIY}

Visi BPAD DIY tahun 2012-2017 adalah Mewujudkan Masyarakat pembelajar yang Berkarakter dan Berbudaya. Dengan misi sebagai berikut: meningkatkan pengelolaan dan pemanfaatan perpustakaan dan arsip secara optimal, mengembangkan jaringan perpustakaan dan kearsipan berbasis

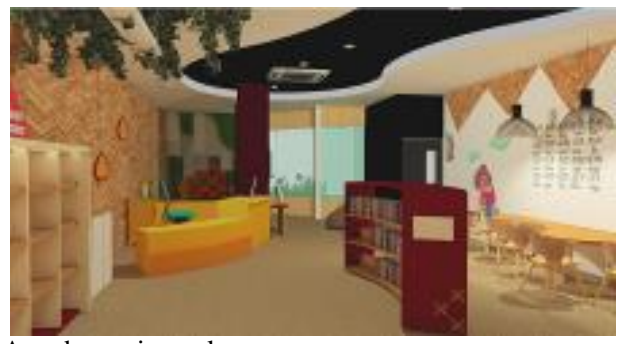

Gambar 4. Area bermain anak.

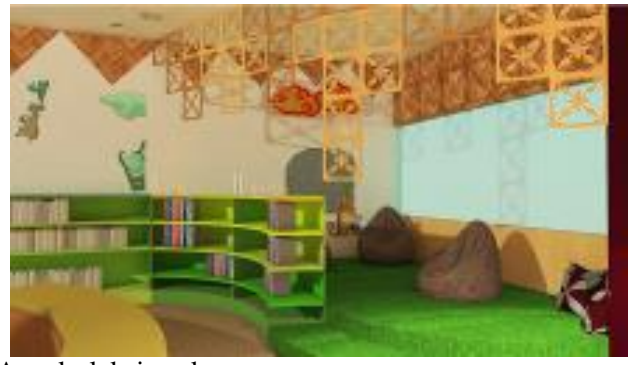

Gambr 5. Area koleksi anak.

Teknologi Informasi, dan ewujudkan Perpustakaan dan Arsip sebagaikhasanah budaya daerah.

\section{Studi Eksisting}

Grhatama Pustaka merupakan sebuah Learning Center yang dirancang untuk memenuhi kebutuhan pendidikan, penelitian, pelestarian, informasi, dan rekreasi bagi masyarakat luas. Diharapkan Grhatama Pustaka mampu menjadi pintu gerbang bagi manusia dalam mencapai derajat tertinggi melalui pengetahuan.

Bangunan perpustakaan Grhatama Pustaka dibangun diatas lahan 2,4 hektar dengan 3 lantai didalamnya. Bagian depan bangunan menghadap utara. Grahatama Pustaka memiliki 5 pintu masuk dengan 3 pintu untuk umum yang lainnya hanya bersifat privat. 


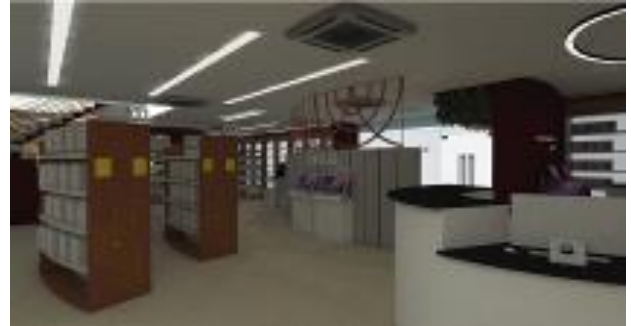

Gambar 6. Area Koleksi Umum.

Terbagi atas beberapa ruang pada setiap lantai, pada lantai basement lebih mengarah ke area anak-anak dan juga kantor. Untuk lantai satu dan dua area public namun tetap terdapat beberapa ruang untuk kantor. (Gambar 2)

\section{Jogja}

Jogjakarta adalah DIY adalah salah satu daerah isitimewa di Indonesia, karena masih menggunakan system kerajaan atau keraton pada system pemerintahannya. Image Jogyakarta yang ada di benak masyarakat adalah kesultanan, gebyok, malioboro, batik, andong, candi, tugu dan kesenian wayang [4].

\section{E. Konsep Mandiri}

Mandiri yang dimaksud adalah menciptakan pola kegiatan pemustaka yang cerdas dan paham lingkungan gedung perpustakaan tanpa bertanya. Penciptaan pola ini dilakukan dengan peletakan dan pemilihan signage dan denah bangunan yang informatif, serta kemudahan pemustaka dalam mengakses setiap fasilitas yang ada. Mandiri pada desain ini mengambil pembentukan pola alur kegiatan.

\section{F. Konsep Rekreatif}

Rekreatif (recreative) dalam kamus Inggris-Indonesia kontemporer memiliki arti: yang menyegarkan dan yang menghibur. Karakter ini dapat dicapai dengan komposisi baik untuk elemen bangunan yang merangsang kreativitas secara psikologis dan kesenangan. Dalam menunjang lingkungan yang rekreatif tentu diperluhkan elemen pendamping seperti warna, dan furnitur.

Rekreatif yang dimaksud adalah penciptaan suasana dan kegiatan yang mendukung pola pikir rekreatif yang menyenangkan dan relaks dari kejenuhan kota jogjakarta. Selain itu menjadikan perpustakaan Grhatama Pustaka sebagai salah satu destinasi wis ata keluarga yang edukatif.

Penggunaan furnitur yang ergonomi dan dinamis tentu sesuai dengan karakter rekreatif yang ingin dibentuk, dengan bentuk yang mengikuti perilaku dari pengguna tentu memberikan kenyaman yang sesuai. Dengan menerapkan pola sirkulasi yang menyenangkan dengan bentukan sirkulasi melingkar, pengunjung dapat merasa lebih senang dibandingkan dengan alur yang monoton. Pola sirkulasi ini memungkinkan pengunjung untukberinteraksi.

\section{G. Studi Khusus}

Segmentasi pengguna perpusatakaan adalah pelajar dan umum. Untuk golongan pelajar dimulai dari rentang SD hingga kuliah, hal ini dimaksudkan untuk pembentukan perilaku serta pemikiran yang baik terbentuk, pembentukan karakter ini dipengaruhi oleh beberapa faktor salah satunya lingkungan internal yang terdiri dari intelegnsi, hormon,

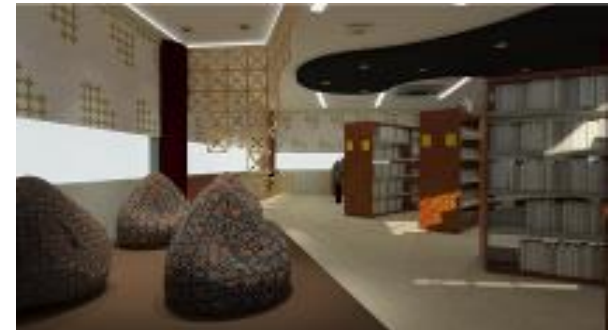

Gambar 7. Area Koleksi Umum.

emosi, dan pola perumbuhan dan perkembangan [5].Untuk mendapatkan pencahayaan yang sesuai dalam suatu ruang, maka diperlukan sistem pencahayaan yang tepat sesuai dengan kebutuhannya. Sistem pencahayaan di ruangan, termasuk di tempat kerja dapat dibedakan menjadi 5 macam yaitu direct lighting, semi direct, general diffuse, semi indirect dan indirect lighting. Yang akan diterapkan pada perpustakaan ini adalah direct dan semi indirect lighting.

\section{METODOLOGI PENELITIAN}

\section{A. Bagan Proses Desain}

Bagan Proses Desain ditunjukkan pada Gambar 3.

\section{B. Metode Pencarian Data}

Metode yang digunakan pada penelitian ini meliputi,

1. Observasi

2. Studi Literatur

3. Kuisioner

\section{Tahap Analisa Data}

Berdasarkan pada pencarian data yang sudah dilakukan terdapat beberapa kesimpulan yang dapat dijadikan kajian dalam proses penyelesaian masalah.

\section{ANALISIS DAN PEMBAHASAN}

\section{A. Perpustakaan Grhatama Pustaka}

Perpustakaan umum propinsi yang berada di Jogjakarta, selaian terdapat buku dan e-jurnal juga terdapat ruang braile, area anak serta ruang audiovisual dan 6D. Hal ini menyebabkan segmen pengguna perpustakaan menjadi beragam daru usia anak-anak hingga dewasa dan juga difabel.

\section{B. Konsep Desain}

Berikut adalah pengaplikasian konsep yang diterapkan pada objek desain :

\section{Konsep Makro}

Konsep makro dijabarkan melalui tema mandiri dan rekreatif. Pada tema mandiri hal yang ingin diselesaikan ditampilkan melalui signage dan teknologi selfservice. Sedangkan tema rekreatif ditampilkan dalam nuansa pada perpustakaan dan juga model furnitur yang modular sehingga gampang jika melakukan penyusunan rak kembali.

2. Konsep Mikro

a. Konsep Bentuk

Bentuk yang digunakan pada desain ini berbentuk dinamis, dimana bentukannya sesuai dengan melengkung dan memberikan kesan luas. 


\section{b. Konsep Lantai}

Untuk memberikan kesan nyaman serta meminimalisir suara penggunaan material karpet menjadi pilihan, warna yang digunakan menggunakan warna netral untuk meminimalisir point interest pada desain. Pada area anak penggunaan warna tone alam untuk mereflesikan alam, sehingga sedikit berwarna namun tidak melenceng dari pemilihan konsep warna yang ada.

c. Konsep Material

Material yang digunakan menggunakan plywood serta alumunium steel, dengan finishing warna tone coklat. Khusus pada area anak menggunakan material yang ringan dan aman. Serta terdapat rumput sintetis pada area anak untuk mendukung konsep rekreatif dengan dekat alam

d. Konsep Furnitur

Furnitur menggunakan bentukan dinamis dengan model custom, pada area koleksi umum rak buku dibuat modular hal ini untuk memudahkan penataan ulang apabila diinginkan.

e. Konsep Mandiri

Mandiri dalam desain ini lebih ke hal membebaskan pengunjung dalam mengeksplore perpustakaan dengan sendiri, seperti mulai dari mencari buku hingga meminjam serta mengembalikan buku semua menerapkan sistem self return. Pada area anak juga memberikan wawasan mengenai sistem penataan buku di perpustakaan melalui warna yang terdapat pada rak buku.

f. Konsep Rekreatif

Konsep ini lebih condong kearah menciptakan kenyamanan dan pengalaman baru pada pengunjung melalui desain ruangan, sirkulasi serta fasilitas yang ada pada setiap area, sehingga menciptakan rasa menyenangkan .

\section{PROSES DAN HASIL DESAIN}

\section{A. Pengembangan Desain Ruang Terpilih 1}

Pada area baca anak (Gambar 4), pemanfaatan area sebagai sarana membaca dan bermain terlihat dari layout serta penerapan aplikasi desain mandiri dan rekreatif. Pemilihan warna tone coklat disesuaikan dengan warna tradisional yang dipakai, pemillihan warna hitam pada langit-langit untuk memberikan suasana luar angkasa yang luas. Pengeksploran dinding akuarium yang bisa dilihat dari dalampun memberikan nilai tambahan untuk eksperimen.

Pada area Gambar 5, selain menyediakan kursi membaca juga terdapat bean bag serta sofa panjang untuk membaca anak, untuk penataan sirkulasi yang ada juga disesuaiakan dengan aktivitas anak-anak yang suka berjalan kesana-kemari sehingga bentukan furnitur yang ada lebih dinamis.

\section{B. Pengembangan Desain Ruang Terpilih 2}

Pada area koleksi umum, penggunaan furnitur modular pada konsep memberikan nilai tambahan pada saat kita mengeksplore rak buku, karena secara tidak langsung sirkulasi yang diterapkan memberikan efek bermain.

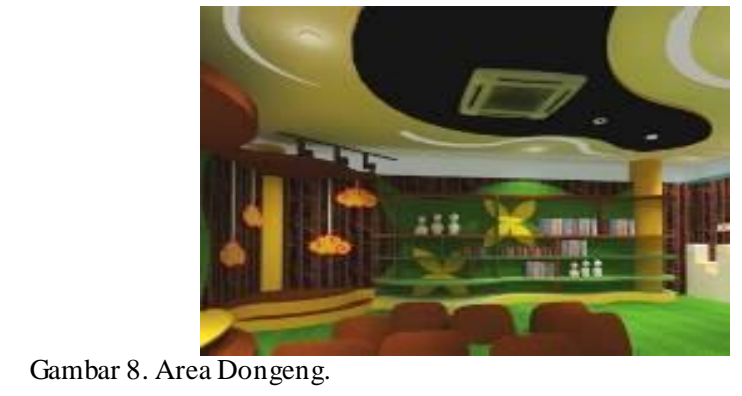

Pada area Gambar 6, pemilihan warna yang diterapkan lebih ke warna coklat yang netral dimana disesuaikan dengan tingkat umur dari pengunjung area ini dimana rata-rata berusia remaja hingga dewasa.

Untuk area koleksi umum lantai 2 lebih mengarah ke area grup diskusi, dimana disediakan area untuk berdiskusi sehingga tidak mengganggu pengunjung lainnya yang datang ke area ini untuk membaca. Penggunaan motif batik truntum terdapat pada ukiran elemen estestis yang terdapat pada area santai, penggunaan motif ini disesuaikan dengan ekterior bangunan yang menggunakan motif batik ini. (Gambar 7)

\section{Pengembangan Desain Ruang Terpilih 3}

Pada area ini (Gambar 8) lebih menciptkan suasana rekreatif alam yang menyengkan, serta eksperimen baru pada anak dimana diterapkan pada ambient lampu pada ceiling serta target spot yang dimaksudkan untuk memberikan efek fokus pada saat mendongeng.

Pada area ini, pengunjung usia anak-anak dapat memilih ingin posisi membaca dongeng seperti apa, karena pada area ini terdapat 3 spot untuk mendongeng, dan dapat juga diperuntukan untuk anak-anak mendongeng dengan gaya mereka sendiri, warna dominan hijau pada area ini untuk memberikan kesan alam dan suasana baru diperkotaan yang cenderung terisi bangunan.

\section{KESIMPULAN}

Perpustakaan Ghratama Pustaka adalah sebuah perpustakaan model baru yang terdapat di Jogjakarta, dengan beragam fasiltas yang ditawarkan menjadikannya sebuah perpustakaan yang cukup dijadikan acuan, namun disayangkan dengan beragamnya fasilitas yang ada kurang dibarengi dengan pengoptimalan area yang ada serta sedikitnya signage pada bangunan membuat beberapa orang kesusahan. Dengan penerapan desain yang mandiri dan rekreatif diharapkan perpustakaan ini menjadi lebih baik kedepannya.

\section{DAFTAR PUSTAKA}

[1] Soetminah, Perpustakaan, Kapustakaan dan Pustakawan. Yogyakarta: Kanisius, 1992.

[2] Pemerintahan Republik Indonesia, "Undang-Undang Perpustak aan Nomor 43 Tahun 2007," 2007.

[3] N. Sut arno, Manajemen perpustakaan: suatu pendekatan praktik. Jakarta: Sagung Seto, 2006.

[4] A. A. Rucita and M. Indira Prabawati, "Desain Interior Terminal Penumpang Domestik 'A' Bandara Adisucipto Berdasark an Daya Tarik Kota Yogyakarta,” J. Desain Inter., 2016.

[5] Darmono, Perpustakaan Sekolah: Pendekatan Aspek Manajemen dan Tata Kerja. Jakarta: Grasindo, 2007. 